\begin{tabular}{|c|c|c|c|}
\hline Case Reports in & \multicolumn{2}{|c|}{ Case Rep Gastroenterol 2017;11:219-224 } & \multirow[b]{2}{*}{$\begin{array}{l}\text { Karger } \\
\text { Opengaccess }\end{array}$} \\
\hline Gastroenterology & $\begin{array}{l}\text { DOI: 10.1159/000448069 } \\
\text { Publisned onIIne: April I9, } 2017\end{array}$ & $\begin{array}{l}\text { (C) } 2017 \text { The Author(s) } \\
\text { Published by S. Karger AG, Basel } \\
\text { www.karger.com/crg }\end{array}$ & \\
\hline & $\begin{array}{l}\text { This article is licensed under } \\
\text { International License (CC BY- }- \\
\text { Usage and distribution for comn }\end{array}$ & $\begin{array}{l}\text { mons Attribution-NonCommercial } 4 . \\
\text { ger.com/Services/OpenAccessLicense) } \\
\text { quires written permission. }\end{array}$ & \\
\hline
\end{tabular}

\title{
Pancreatic Squamous Cell Carcinoma
}

\author{
Seyed Hassan Abedi ${ }^{a} \quad$ Alireza Ahmadzadeh $^{\mathrm{a}, \mathrm{b}}$ \\ Amir Houshang Mohammad Alizadeha \\ ${ }^{a}$ Shahid Beheshti University of Medical Sciences, Taleghani Hospital, Tehran, Iran; \\ ${ }^{b}$ Faculty of Medicine, Ilam University of Medical Sciences, Tehran, Iran
}

\section{Keywords}

Pancreas · Squamous cell carcinoma · Endoscopic ultrasound-guided fine needle aspiration

\begin{abstract}
Pancreatic squamous cell carcinoma (SCC) is a rare event. Here, we present a 56-year-old man with pancreatic SCC. Imaging methods demonstrated a hypodense mass at the head and trunk of the pancreas. Also, some lymphadenopathy has been seen around the pancreas and para-aorta. The mass created pressure and encasement on the celiac trunk, portal vein, and arteries of the liver and spleen. Endoscopic ultrasound showed a mass lesion of 45-37 $\mathrm{mm}$ (mixed echoic) at the trunk of the pancreas. Histological examination of the endoscopic ultrasound-guided fine needle aspiration specimen confirmed the diagnosis of SCC. The disease is highly aggressive, most often locally advanced or metastatic at diagnosis, and poorly responsive to treatment. It also has generally poor survival rates.

(C) 2016 The Author(s)

Published by S. Karger AG, Basel
\end{abstract}

\section{Introduction}

The majority of pancreatic carcinomas are primary tumors. Lately, expansion of imaging techniques led to more consideration for tumors of the pancreas [1]. Normally, the pancreas lacks squamous epithelium. During periods of inflammation such as in pancreatitis and squamous cell carcinoma (SCC) these cells can be observed [2]. The pancreas neoplasms are 
classified as endocrine or non-endocrine. Based on the location of the tumor, non-endocrine neoplasms can have five different sources: acinar, connective tissue, ductal, mixed cell type, and uncertain origin [3]. Also, the pancreatic ductal malignancy can be subdivided into adenocarcinoma and SCC. SCC of the pancreas is a controversial entity of uncertain origin [4]. Pancreatic SCC is a primary rare malignancy $[5,6]$. It accounts for approximately $0.5-2 \%$ of all malignant pancreatic tumors [7]. Because it is an infrequent disorder, a diagnosis of primary pancreatic SCC is made only after excluding other neoplastic lesions of the pancreas that contain squamous epithelial components [2]. The main differential diagnoses of primary SCC of the pancreas are adenosquamous carcinoma (ASC) - another rare primary tumor of the pancreas - and metastatic SCC from another primary site [8]. Here, we describe a patient with pancreatic SCC along with the clinicopathological features.

\section{Case Report}

Three months ago, a 56-year-old man with epigastric and right upper quadrant pain was admitted to a hospital. The disease was diagnosed as gallstones and cholecystectomy was done for the patient. After surgery, not only did the symptoms resolve but also loss of appetite and weight (15\%) were added to the clinical signs. The patient was referred to our hospital because of abdominal pain. Subsequently, physical examination was done. Initial laboratory evaluation revealed moderate elevations of amylase $215 \mathrm{IU} / \mathrm{L}$ (normal up to $100 \mathrm{IU} / \mathrm{L}$ ) and lipase $130 \mathrm{IU} / \mathrm{L}$ (normal up to $60 \mathrm{IU} / \mathrm{L}$ ) along with mild anemia (Hb $11.5 \mathrm{~g} / \mathrm{dL}$ ). Blood samples taken at the time of admission and clinical parameters were as follows: BUN 13 $\mathrm{mg} / \mathrm{dL}$ (normal range $8-20 \mathrm{mg} / \mathrm{dL}$ ); $\mathrm{Cr} 1.5 \mathrm{mg} / \mathrm{dL}$ (normal range for male $0.6-1.3 \mathrm{mg} / \mathrm{dL}$ ); uric acid $3.3 \mathrm{mg} / \mathrm{dL}$ (normal range for male 3.6-7.7 mg/dL); TG $88 \mathrm{mg} / \mathrm{dL}$ (normal range up to $150 \mathrm{mg} / \mathrm{dL}$ ); cholesterol $124 \mathrm{mg} / \mathrm{dL}$ (desired <200); Ca $7 \mathrm{mg} / \mathrm{dL}$ (normal range 8.5-10.5 $\mathrm{mg} / \mathrm{dL}$ ); ph $3.8 \mathrm{mg} / \mathrm{dL}$ (normal range $2.7-5 \mathrm{mg} / \mathrm{dL}$ ); Na $133 \mathrm{mEq} / \mathrm{L}$ (normal range 135-145 $\mathrm{mEq} / \mathrm{L}$ ); K 4.2 (normal range 3.5-5 mEq/L); AST 17 IU/L (normal <40); ALT 11 IU/L (normal <40); ALP 193; LDH 301 IU/L (normal 225-450 IU/L); amylase 88 IU/L (normal up to $100 \mathrm{IU} / \mathrm{L}$ ); lipase $66 \mathrm{IU} / \mathrm{L}$ (normal up to $60 \mathrm{IU} / \mathrm{L}$ ); total protein $6.2 \mathrm{IU} / \mathrm{L}$ (normal 6.6-8.3 $\mathrm{IU} / \mathrm{L}$ ); albumin $3.9 \mathrm{~g} / \mathrm{dL}$ (normal 3.5-5.2 g/dL); total bilirubin $0.4 \mathrm{mg} / \mathrm{dL}$ (normal 0.3$2 \mathrm{mg} / \mathrm{dL}$ ); direct bilirubin $0.2 \mathrm{mg} / \mathrm{dL}$ (normal $<1 \mathrm{mg} / \mathrm{dL}$ ); WBC $6.1 \times 10^{3} / \mu \mathrm{L} ; \mathrm{RBC} 4.5 \times$ $10^{3} / \mu \mathrm{L} ; \mathrm{HGB} 11.5 \mathrm{~g} / \mathrm{dL}$ (normal 13-16 g/dL); HCT 33.9\% (normal 39-48\%); MCV $79.8 \mathrm{fL}$ (normal 80-100); MCH $27.1 \mathrm{pg}$ (normal 26-34.4); MCHC $33.9 \mathrm{~g} / \mathrm{dL}$ (normal 31.8-36.3 g/ $\mathrm{dL})$; PLT $399 \times 10^{3} / \mu \mathrm{L}$ (normal $150-400 \times 10^{3} / \mu \mathrm{L}$ ).

The initial diagnosis was unclear and the patient underwent computed tomography (CT) of the abdomen for further evaluation (Fig. 1). The CT showed the presence of a hypodense mass at the head and trunk of the pancreas. Also, some lymphadenopathy has been seen around the pancreas and para-aorta. The mass created a pressure and encasement on the celiac trunk, portal vein, and arteries of the liver and spleen. For further evaluation, endoscopic ultrasound (EUS)-guided fine needle aspiration (FNA) was performed (Fig. 2). EUS showed a mass lesion of 45-37 mm (mixed echoic) at the trunk of the pancreas invading the splenic vein and artery. The pancreatic duct was $7 \mathrm{~mm}$ at the tail of the pancreas. FNA samples from the pancreas were sent for pathological examination (Fig. 3).

Pathological finding indicated sheets of malignant cells with round to oval nuclei with thick nuclear membrane. Occasional prominent nucleoli and high N/C ratio cytoplasm were eosinophilic granular and moderate to abundant with rather well-defined borders. The chromatin pattern was coarse and the mitotic figures were easy to find. Cytologic study was 
positive for SCC and further confirmed by immunohistochemistry. The immunohistochemical studies (Fig. 4) were performed using antihuman antibodies against the following markers: unlike CEA, which was negative in tumor cells, CK5/6 and P63 were strongly positive in tumor cells.

The definitive diagnosis of pancreatic SCC was justified by immunohistochemical and pathological study; thus, the patient was sent for chemotherapy. The patient received chemotherapy with gemzar and oxaliplatin (GEMOX at doses of 1,000 and $100 \mathrm{mg} / \mathrm{m}^{2}$ ) for $4 \mathrm{cy}-$ cles. He had no response to treatment and chemotherapy was changed to weekly irinotecan (140 mg weekly). Four months after chemotherapy, clinical signs continued and abdominal CT was done again (Fig. 5). Although chemotherapy was done for the patient, the CT image revealed a development in SCC of the pancreas.

\section{Discussion}

Pancreatic SCC is a rare exocrine pancreatic carcinoma [9]. There are different reports for the incidence of SCC, ranging from 0.5 to $5 \%$ [10]. The histogenesis of pancreatic SCC is vague, but there are some hypotheses: (1) a bipotential primitive cell capable of differentiating into either squamous or glandular carcinoma undergoes malignant change; (2) squamous metaplasia of the ductal epithelium undergoes a malignant transformation; (3) preexisting adenocarcinoma undergoes squamous change; or (4) an atypical squamous cell undergoes a malignant change $[11,12]$. The prominent feature of pancreatic SCC is similar to ductal adenocarcinoma including upper abdominal and back pain, anorexia, weight loss, nausea, fatigue, vomiting, and obstructive jaundice [13]. Local lymph node involvement and liver metastases are common with this tumor [14]. At present, a tumor blush in angiography and endoscopic retrograde cholangiopancreatography or enhancement of the tumor on contrast CT can be useful in SCC diagnosis [15-17]. However, EUS-FNA has been increasingly accepted for the identification of pancreatic malignancies with a high sensitivity and specificity [18]. The disease has a poor prognosis and the survival from the time of diagnosis is similar to that of pancreatic adenocarcinoma [19]. Although different therapeutic methods have been used in the handling of pancreatic SCC, which include surgical resection, chemotherapeutic regimens, and radiotherapy, none have been proven effective [20].

\section{Statement of Ethics}

All procedures and data gathering were performed by the patient's informed consent.

\section{Disclosure Statement}

The authors declare that they have no conflict of interest. 
Abedi et al.: Pancreatic Squamous Cell Carcinoma

\section{References}

1 Muranaka T, et al: Computed tomography and histologic appearance of pancreatic metastases from distant sources. Acta Radiol 1989;30:615-619.

2 Layfield LJ, et al: Atypical squamous epithelium in cytologic specimens from the pancreas: cytological differential diagnosis and clinical implications. Diagn Cytopathol 2001;25:38-42.

-3 Cubila AL, Fitzgerald PJ: Classification of pancreas cancer (non-endocrine). J Pancreas 2011;54:445449.

4 Nikfam S, et al: Squamous cell carcinoma of the pancreas. Arch Iran Med 2013;16:369-370.

5 Kardon DE, et al: Adenosquamous carcinoma of the pancreas: a clinicopathologic series of 25 cases. Mod Pathol 2001;14:443-451.

-6 Zacharia G, et al: Primary squamous cell carcinoma of the pancreas diagnosed by endoscopic ultrasound-guided fine needle aspiration. J Gastrointestin Liver Dis 2012;21:321-323.

7 Schultheis AM, et al: Squamous cell carcinoma of the pancreas in a patient with germline BRCA2 mutation-response to neoadjuvant radiochemotherapy. Case Rep Oncol Med 2014;2014:860532.

-8 Bixler HA, Castro MJ, Stewart J: Cytologic differentiation of squamous elements in the pancreas. Diagn Cytopathol 2011;39:536-540.

-9 Baylor SM, Berg JW: Cross-classification and survival characteristics of 5000 cases of cancer of the pancreas. J Surg Oncol 1973;5:335-358.

10 Beyer KL, et al: Squamous cell carcinoma of the pancreas. Report of an unusual case and review of the literature. Dig Dis Sci 1992;37:312-318.

11 Bralet MP, Terris B, Bregeaud L, Ruszniewski P, Bernades P, Belghiti J, et al. Squamous cell carcinoma and lipomatous pseudohypertrophy of the pancreas. J Virchows Arch 1999;434:569-572.

12 Motojima K, Tomioka T, Kohara N, Tsunoda T, Kanematsu T: Immunohistochemical characteristics of adenosquamous carcinoma of the pancreas. J Surg Oncol 1992;49:58-62.

13 Minami T, Fukui K, Morita Y, et al: A case of squamous cell carcinoma of the pancreas with an initial symptom of tarry stool. J Gastroenterol Hepatol 2001;16:1077-1079.

14 Park C, et al: A case of esophageal squamous cell carcinoma with pancreatic metastasis. Clin Endosc 2013;46:197-200.

15 Sprayregen S, Schoenbaum SW, Messinger NH: Angiographic features of squamous cell carcinoma of the pancreas. J Can Assoc Radiol 1975;2:122-124.

16 Koduri VG, Ravi TJ: Squamous cell carcinoma of the pancreas: report of a case and review of ERCP findings. J Endoscopy 1994;26:333-334. Al-Shehri A, Silverman S: Squamous cell carcinoma of the pancreas. J Curr Oncol 2008;15:293-297. FNA: a case report. World J Gastroenterol 2009;15:4343-4345.

19 Pour P, Kruger FW, Althoff J, Cardesa A, Mohr U: Cancer of the pancreas induced in the Syrian golden hamster. Am J Pathol 1974;54:449-458.

20 Brown HA, Dotto J, Robert M, Salem RR: Squamous cell carcinoma of the pancreas. J Clin Gastroenterol 2005;39:915-919. 


\begin{tabular}{|c|c|c|}
\hline \multirow{2}{*}{$\begin{array}{l}\text { Case Reports in } \\
\text { Gastroenterology }\end{array}$} & \multicolumn{2}{|c|}{ Case Rep Gastroenterol 2017;11:219-224 } \\
\hline & DOI: $10.1159 / 000448069$ & $\begin{array}{l}\text { ( ) } 2016 \text { The Author(s). Published by S. Karger AG, Basel } \\
\text { www.karger.com/crg }\end{array}$ \\
\hline
\end{tabular}

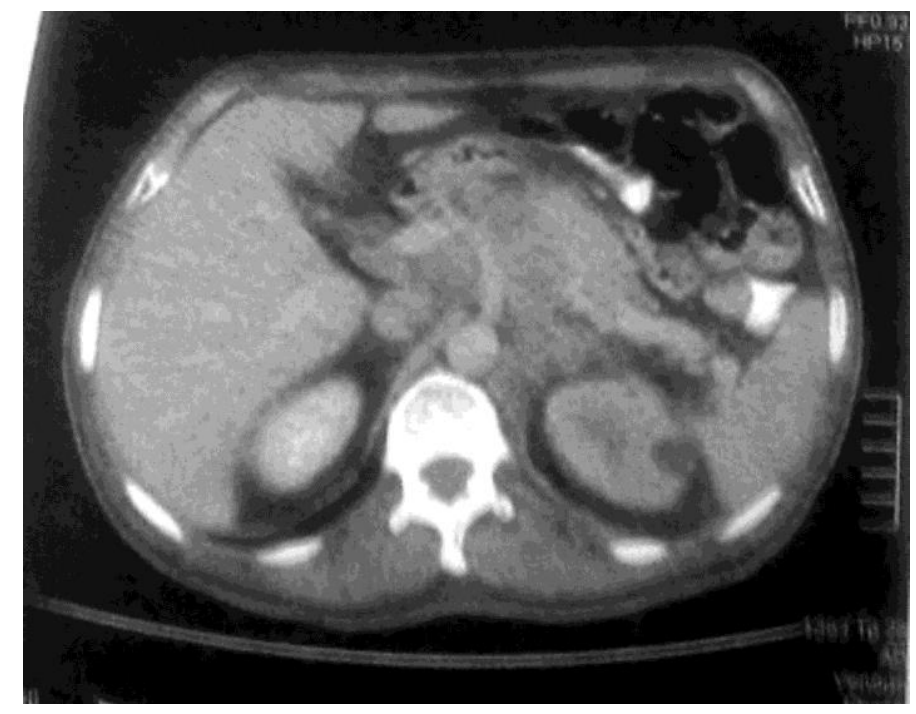

Fig. 1. CT of the abdomen using pancreatic protocol.

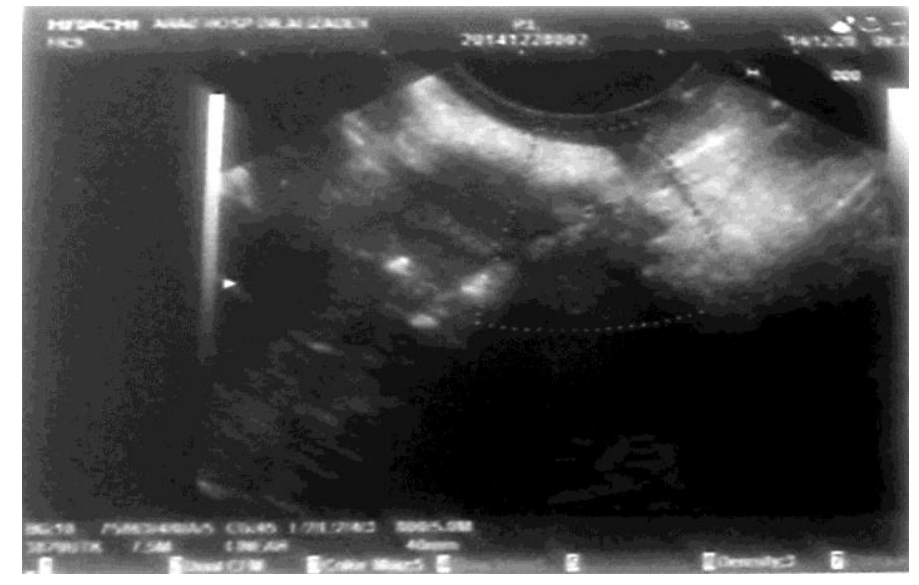

Fig. 2. EUS image of the pancreas with squamous cell carcinoma. 


\section{Case Reports in Gastroenterology}

\begin{tabular}{l|l}
\hline Case Rep Gastroenterol 2017;11:219-224 \\
\hline DOI: 10.1159/000448069 & $\begin{array}{l}\text { C 2016 The Author(s). Published by S. Karger AG, Basel } \\
\text { www.karger.com/crg }\end{array}$ \\
\hline
\end{tabular}

Abedi et al.: Pancreatic Squamous Cell Carcinoma
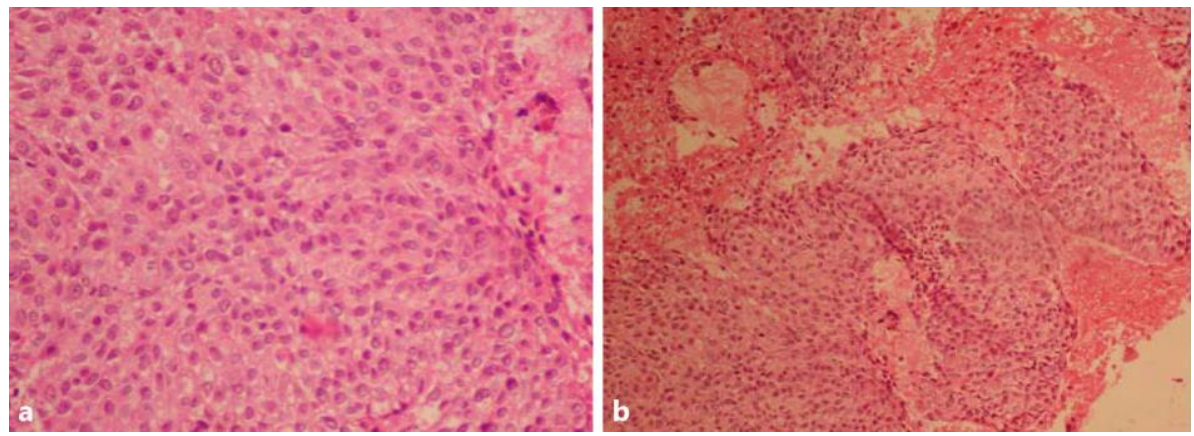

Fig. 3. The neoplasm is composed of many malignant cells with round to oval nuclei (HE). a Sheets of malignant cells with round to oval nuclei with thick nuclear membrane. b Prominent nucleoli and high N/C ratio cytoplasm which are eosinophilic granular and moderate to abundant with rather well-defined borders.
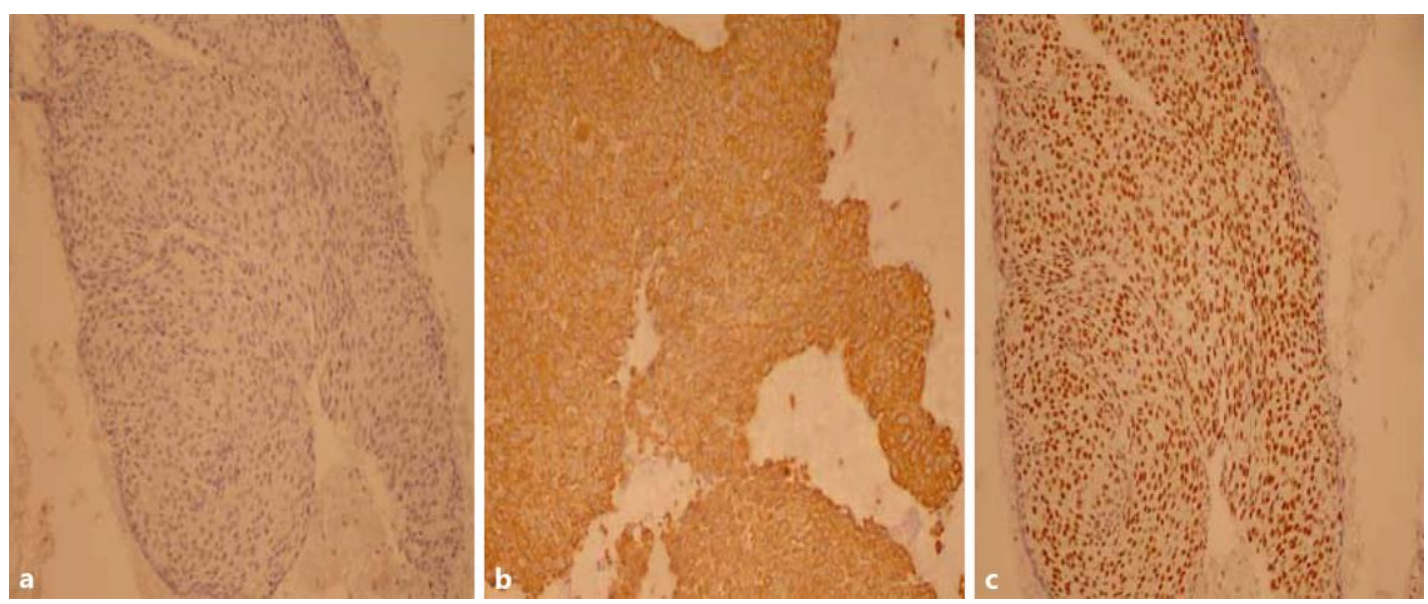

Fig. 4. The CEA marker (a) is negative, the CK5/6 (b) and P63 (c) markers are positive.

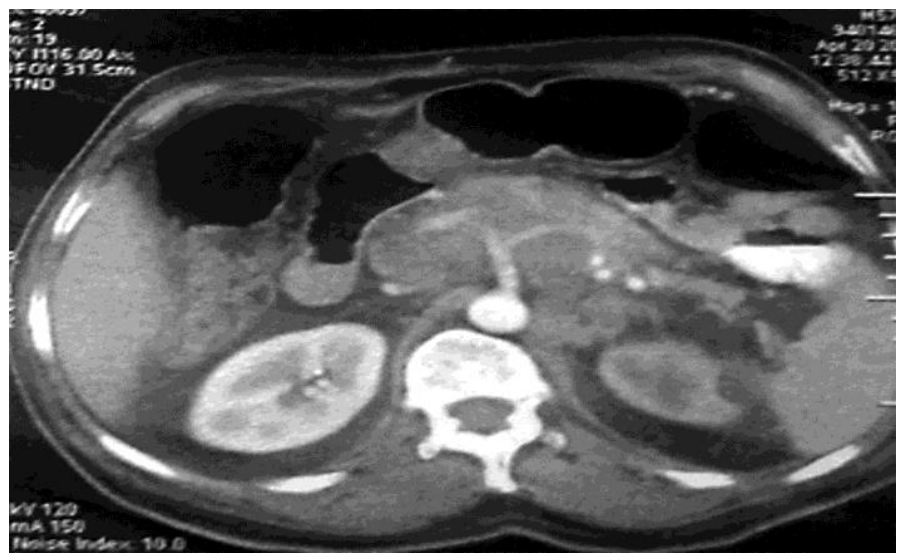

Fig. 5. Abdominal axial CT scan depicting a developed pancreatic SCC. 